Egyptian Journal of Aquatic Biology \& Fisheries

Zoology Department, Faculty of Science,

Ain Shams University, Cairo, Egypt.

ISSN $1110-6131$

Vol. 25(4): 271 - 284 (2021)

www.ejabf.journals.ekb.eg

\title{
Impact of Temperature Elevation on Seawater Snail Planaxis sulcatus
}

\author{
Yaser S. Binnaser \\ Department of Biology, College of Science, Taibah University, Saudi Arabia \\ ysbinnaser@gmail.com
}

\begin{abstract}
ARTICLE INFO
Article History:

Received: June 10, 2021

Accepted: July 27, 2021

Online: Aug. 9, 2021

Keywords:

Planaxis sulcatus;

Elevated temperature;

Global warming;

Climate change;

Red sea.

ABSTRACT

To assess the effect of temperature on wet weight, shell length, and shell aperture of seawater snail Planaxis sulcatus, an experimental trial was conducted to examine 72 samples of this species. The specimens were collected from the area of Al-Rayis coast on the western side of Saudi Arabia and were divided into 3 groups; A, B, and C (24 snails/group). Group A was the control group. Group B was treated by increasing water temperature about $5^{\circ} \mathrm{C}$ above the control group, and about $10^{\circ} \mathrm{C}$ above the control group for group C. There were no significant differences in weekly wet weight measurements with respect to the intragroup comparison and the intergroup comparison of the three groups. However, regarding shield length, it increased at week 1 with a pairwise comparison of weekly records showing only a significant difference between the $1^{\text {st }}$ week and that of the onset of the study in group A. While, in group B, results showed only a significant difference between week 3 and week 6 , and no significant difference was detected in group C. In addition, no significant differences were recorded when the 3 groups' shield lengths were compared. Hence, it is recommended to conduct complex experiments that depend on exposing snails to several climate change factors, such as increased acidity and salinity in addition to high temperature.
\end{abstract}

\section{INTRODUCTION}

Since the year 1950, the climate has witnessed an obvious change, including temperature change, hurricanes and high levels of saline seawater precipitation amounts (IPCC, 2014), and this has remarkably been due to the natural global effect or to human activities (Gravili et al., 2017). Global warming is one of these climate changes spotlighted by the Intergovernmental Panel on Climate Change (IPCC) which predicts that global mean sea water temperature will increase from $2-4.5^{\circ} \mathrm{C}$ by 2100 (scenario RCP 8.5, (Intergovernmental Panel on Climate Change, 2013). Inc. global warming of $1.5^{\circ} \mathrm{C}-2.5^{\circ} \mathrm{C}$ is predicted to cause extinction of about third of biological species (Dow $\boldsymbol{Q}$ Downing, 2011).

Planaxis sulcatus belongs to the Anemalia kingdom, Mollusca phylum, Gastropoda class, Neotaenioglossa snails order, family of Planaxis, species: Sulcatus (Born, 1978). Gastropods are the largest class of mollusks including about 30,000 marine 
species. The Furrowed Clusterwink (Planaxis sulcatus) is found commonly in the rocky intertidal environments. The conical shell, speckled with patterns of white spots on a greenish-brown background of $P$. sulcatus, grows up to a length of $35 \mathrm{~mm}$ in adult individuals. The $P$. sulcatus are herbivorous, feeding primarily on microalgae growing on the substrates in the habitats (Houbrick, 1987). Females are usually larger than males (OHGAKI, 1997).

The $P$. sulcatus withdraws into its shell behind the operculum attaching itself to the substratum during low tides (Ruppert, 2004). Therefore, it can be seen on rocks and stones in aggregates or taking shelter in rock pools, crevices and under large rocks during the low tides (Houbrick, 1987). Snails are of medical importance as they act as intermediate hosts for many parasites during their life cycles (Dore, 1991). Most of the $P$. sulcatus act as hosts for many trematode species and are usually heavily infected by one or more species of trematodes (Rohde 1981).

The daily and seasonal variation in temperature affects the metapolism of the P.sulcatus, their activity level and energy balance. Furthermore, mostly the rates of physiological and biochemical activities are affected by temperature (Precht $\&$ Herbert, 1973). Notably, the increase in behavioral activity is attributed to the increase of sea water temperature; the outcome of oxygen consumption increase. This, in return, leads to a decrease in the energy storage in the body of marine organisms causing a decline in physical growth rate (Levinton, 2009). Consequently, the global warming is expected to decrease body size of those organisms (Mazurkiewicz et al., 2020). Therefore, warming decreases their biomass through affecting interaction with food web due to increasing energy demand and metabolic processes (Bruno et al., 2015). Marigómez et al. (2017) reported a gradual reduction in weight of the sea cucumber, Apostichopus japonicus, due to the gradual rise in the environmental temperature where it lives. The previous authors added that, an additional increase in current temperatures is feared to exacerbate global warming negative effects, as these organisms are likely to be affected by sea warming. Thus, it is important to predict effects of climate changes on these organisms. However, these physiological and biochemical activities do not depend mostly on environmental temperature as these activities can compensate for variations (Precht \& Herbert, 1973). This compensation is called acclimation if it is induced by a single environmental factor (such as temperature) in the laboratory. If this compensatory change is due to the temperature changes, it is called thermal acclimation (Yanzeel, 1998).

Kim et al. (2004) examined the effects of the harmful red tide on the dinoflagellate, Cochlodinium polykrikoides, and recorded optimum growth rates at temperatures 21 to $26^{\circ} \mathrm{C}$ and salinities from 30 to $36^{\circ} \mathrm{C}$. They added that, when temperature was lower than $10^{\circ} \mathrm{C}$, no growth occurred. Moreover, they noted that growth occurred at temperature from 15 to $30^{\circ} \mathrm{C}$ and salinities from 20 to $36^{\circ} \mathrm{C}$. Therefore, this study aimed to assess the effect of temperature on wet weight, shell length and shell aperture of seawater snail Planaxis sulcatus. 


\section{MATERIALS AND METHODS}

\section{Materials:}

- 72 Planaxis sulcatus snails

- Aquaria (10 L to each one) to place snails

- Cage to keep snails in the bottom of the aquarium

- Digital thermometer (Aqua Medic with an accuracy of $\pm 1^{\circ} \mathrm{C}$ ) to measure water temperatures

- Heaters $(50 \mathrm{~W})$ to provide suitable water temperatures

- Measuring ruler $\mathrm{cm}$ to measure the snail aperture

- Balance to measure the weight of the snail (KERN Precision Balance PCB scale)

- Plastic tie to tie the cage

- Distilled water to balance salinity (when necessary)

- Caliper $\mathrm{cm}$ to measure the length of the snail

- Digital salinity (Aqua Medic with an accuracy of $\pm 2 \mathrm{ppt}$ )

- $\mathrm{pH}$ monitor (Aqua Medic with a resolution of $\pm 0.01 \mathrm{pH}$ )

\section{Collection of samples}

The samples were collected from the area of Al-Rayis coast in the western side of Saudi Arabia (Red sea) where the surface water temperature was $23^{\circ} \mathrm{C}$ (measured $30 \mathrm{~cm}$ below the surface of the seawater). Snails were then transferred to the lab in plastic containers with some rocks containing algae as a temporary food for snails.

Planaxis sulcatus snail was chosen due to its availability in the region and the surrounding areas and it is not one of the endangered species, in order to preserve the biodiversity and abundance of aquatic life in the area.

\section{Adaptation}

Samples in the lab were left for adaptation for five days, then transferred to the Aquaria. Temperature was gradually raised by $0.5^{\circ} \mathrm{C}$ per day for group $\mathrm{B}$, and $1^{\circ} \mathrm{C}$ per day for group $\mathrm{C}$ to reach the target temperature of each aquarium.

\section{Grouping}

Seventy-two samples were divided into 3 groups; A, B and C. Each group contained 24 snails. Group A was the control group. Group B was treated by increasing water temperature about $5^{\circ} \mathrm{C}$ above the control group, while group $\mathrm{C}$ was treated by increasing water temperature about $10^{\circ} \mathrm{C}$ above the control group.

\section{Measurements}

Growth measurements for all samples (wet weight, shield length and shield aperture) were evaluated after 10 days adaptation period qualified to reach the required temperature. Measurements were evaluated once per week.

\section{Statistical analysis}


The collected data were coded, processed and analyzed using Statistical Package of Social Science (SPSS) program for windows (version 16) (Chicago, IL, USA). Quantitative data were presented in mean and standard deviation (SD).

Repeated measures ANOVA test was performed to test significant difference throughout the study period for each group. Bonferroni post hoc test was performed to detect pairwise significance throughout study period. To test the significance between different groups, one way ANOVA test was used. A $p<0.05$ was considered statistically significant, and all analyses were two-sided. Line graphs were established to aid with the demonstration of results.

\section{RESULTS}

During the study period, the seawater measurements of studied groups revealed that in group $\mathrm{A}$, the mean temperature, salinity and acidity were $25.3 \pm 1.2^{\circ} \mathrm{C}, 39.08 \pm$ $0.73 \mathrm{ppm}$ and $8.10 \pm 0.09$, respectively. Seawater measurements of temperature, salinity and the $\mathrm{pH}$ increased gradually in group $\mathrm{B}\left(29.6 \pm 1.2^{\circ} \mathrm{C}, 39.55 \pm 0.95 \mathrm{ppm}\right.$, and $8.06 \pm$ $0.10)$ and group $\mathrm{C}\left(35.4 \pm 0.6^{\circ} \mathrm{C}, 39.76 \pm 1.57 \mathrm{ppm}\right.$, and $\left.8.02 \pm 0.13\right)$, respectively.

Changes in the wet weight of studied snails were considered. It was noticed that, in group $\mathrm{A}$, the wet weight started at $1.00 \pm 0.27 \mathrm{~g}$ in the beginning of the study to reach $0.94 \pm 0.25 \mathrm{~g}$ by the end of $6^{\text {th }}$ week without any significant differences between weekly measures of the wet weight (Fig. 1). Regarding group B, the wet weight started at $0.98 \pm$ $0.26 \mathrm{~g}$ and reached $1.06 \pm 0.23 \mathrm{~g}$ by the end of $6^{\text {th }}$ week, without any significant differences between weekly measures of the wet weight as seen in Fig. (1). In group C, the wet weight started at $1.02 \pm 0.19 \mathrm{~g}$ in the beginning of the study to reach $0.99 \pm 0.14$ $\mathrm{g}$ by the end of $6^{\text {th }}$ week without any significant differences between weekly measures of the wet weight (Fig. 1).

Changes in shield length were regarded for the studied species of snails. It was noticed that in group A, the shield length started at $1.32 \pm 0.13 \mathrm{~g}$ in the beginning of the study to reach $1.27 \pm 0.12$ by the end of $6^{\text {th }}$ week. Pairwise comparison of weekly shield length records showed only a significant difference between the $1^{\text {st }}$ week with reading $(1.29 \pm 0.17)$ and that of the onset of study (1.32 \pm 0.13$)$ (Fig. 2). Regarding group B, the shield length started at $1.30 \pm 0.07$ in the beginning of the study to reach $1.32 \pm 0.11$ by the end of the $6^{\text {th }}$ week. Pairwise comparison of weekly shield length records shows only a significant difference between reading during week $3(1.25 \pm 0.1)$ and that of the end of study $(1.32 \pm 0.11)$ (Fig. 2). For group C, the shield length started at $1.30 \pm 0.10$ in the beginning of the study to reach $1.30 \pm 0.06$ by the end of the $6^{\text {th }}$ week without any significant differences between weekly measures of shield length (Fig. 2).

Changes in in shield aperture of the snails were addressed throughout this study. It was noticed that in group A, the shield length started at $0.99 \pm 0.14 \mathrm{~g}$ in the beginning of the study to reach $1.00 \pm 0.11$ by the end of the $6^{\text {th }}$ week; without any significant 
differences between weekly measures of shield opening (Fig. 3). Regarding group B, the shield length started at $0.98 \pm 0.08$ in the beginning of the study to reach $1.00 \pm 0.06$ by the end of the $6^{\text {th }}$ week; without any significant differences between weekly measures of shield opening (Fig. 3). Regarding group $C$ the shield length started at $0.99 \pm 0.06$ in the beginning of the study to reach $0.98 \pm 0.04$ by the end of the $6^{\text {th }}$ week without any significant differences between weekly measures of shield opening (Fig. 3).

Comparison between the three studied groups regarding the weekly assessed wet weight of snails is presented in Table (1). It revealed no significant difference in the wet weight at any station of the study. Regarding the shield length, comparison of the weekly assessment revealed no significant difference in the shield length at any station of the study (Table 2). In addition, the comparison between the three studied groups regarding their weekly assessed shield aperture of snails showed no significant difference in the shield aperture at any station of the study (Table 3).

Table 1. Comparison between the studied groups regarding the wet weight $(\mathrm{g})$ of the Planaxis sulcatus throughout study period $(\mathrm{n}=24)$

\begin{tabular}{|c|c|c|c|}
\hline \multirow[b]{2}{*}{ Study period } & \multicolumn{3}{|c|}{ Wet weight in (g) } \\
\hline & $\begin{array}{c}\text { Group A } \\
\text { Mean } \pm \text { SD }\end{array}$ & $\begin{array}{c}\text { Group B } \\
\text { Mean } \pm \text { SD }\end{array}$ & $\begin{array}{c}\text { Group C } \\
\text { Mean } \pm \text { SD }\end{array}$ \\
\hline Week 0 & $1.00 \pm 0.27$ & $\begin{array}{l}0.98 \pm 0.26 \\
P 1=0.868\end{array}$ & $\begin{array}{l}1.02 \pm 0.19 \\
\mathrm{P} 2=0.893 \\
\mathrm{P} 3=0.738\end{array}$ \\
\hline Week 1 & $1.06 \pm 0.34$ & $\begin{array}{l}1.05 \pm 0.26 \\
\mathrm{P} 1=0.943\end{array}$ & $\begin{array}{l}1.02 \pm 0.16 \\
\mathrm{P} 2=0.801 \\
\mathrm{P} 3=0.833\end{array}$ \\
\hline Week 2 & $1.04 \pm 0.34$ & $\begin{array}{l}1.08 \pm 0.22 \\
P 1=0.761\end{array}$ & $\begin{array}{l}1.00 \pm 0.14 \\
\mathrm{P} 2=0.773 \\
\mathrm{P} 3=0.384\end{array}$ \\
\hline Week 3 & $0.97 \pm 0.27$ & $\begin{array}{l}1.07 \pm 0.23 \\
P 1=0.481\end{array}$ & $\begin{array}{l}0.99 \pm 0.14 \\
P 2=0.853 \\
P 3=0.436\end{array}$ \\
\hline Week 4 & $0.95 \pm 0.26$ & $\begin{array}{l}1.06 \pm 0.23 \\
P 1=0.383\end{array}$ & $\begin{array}{l}0.99 \pm 0.14 \\
\mathrm{P} 2=0.652 \\
\mathrm{P} 3=0.478\end{array}$ \\
\hline Week 5 & $0.94 \pm 0.25$ & $\begin{array}{l}1.06 \pm 0.24 \\
P 1=0.392\end{array}$ & $\begin{array}{l}0.99 \pm 0.13 \\
\mathrm{P} 2=0.629 \\
\mathrm{P} 3=0.514\end{array}$ \\
\hline Week 6 & $0.94 \pm 0.25$ & $\begin{array}{l}1.06 \pm 0.23 \\
P 1=0.382\end{array}$ & $\begin{array}{l}0.99 \pm 0.14 \\
P 2=0.637 \\
P 3=0.495\end{array}$ \\
\hline
\end{tabular}

One way ANOVA test was used with Bonferroni post hoc test. A p-value less than 0.05 was considered statistically significant.

P1 compare group B vs. group A $\mathrm{P} 2$ compare group $\mathrm{C}$ vs. group A P3 compare group B vs. group C 
Table 2. Comparison between the studied groups regarding the length $(\mathrm{cm})$ of Planaxis sulcatus throughout study period, $(\mathrm{n}=24)$

\begin{tabular}{|c|c|c|c|}
\hline \multirow[b]{2}{*}{ Study period } & \multicolumn{3}{|c|}{ Shield length in $(\mathrm{cm})$} \\
\hline & $\begin{array}{c}\text { Group A } \\
\text { Mean } \pm \text { SD }\end{array}$ & $\begin{array}{c}\text { Group B } \\
\text { Mean } \pm \text { SD }\end{array}$ & $\begin{array}{c}\text { Group C } \\
\text { Mean } \pm \text { SD }\end{array}$ \\
\hline Week 0 & $1.32 \pm 0.13$ & $\begin{array}{l}1.30 \pm 0.07 \\
P 1=0.702\end{array}$ & $\begin{array}{c}1.30 \pm 0.10 \\
\mathrm{P} 2=0.724 \\
\mathrm{P} 3=1.00\end{array}$ \\
\hline Week 1 & $1.29 \pm 0.17$ & $\begin{array}{l}1.34 \pm 0.13 \\
P 1=0.485\end{array}$ & $\begin{array}{l}1.28 \pm 0.06 \\
\mathrm{P} 2=0.898 \\
\mathrm{P} 3=0.231\end{array}$ \\
\hline Week 2 & $1.29 \pm 0.18$ & $\begin{array}{l}1.29 \pm 0.12 \\
P 1=0.769\end{array}$ & $\begin{array}{l}1.29 \pm 0.09 \\
\mathrm{P} 2=0.861 \\
\mathrm{P} 3=0.841\end{array}$ \\
\hline Week 3 & $1.26 \pm 0.15$ & $\begin{array}{l}1.25 \pm 0.10 \\
P 1=0.600\end{array}$ & $\begin{array}{l}1.27 \pm 0.09 \\
\mathrm{P} 2=0.591 \\
\mathrm{P} 3=0.992\end{array}$ \\
\hline Week 4 & $1.27 \pm 0.12$ & $\begin{array}{l}1.29 \pm 0.12 \\
P 1=0.303\end{array}$ & $\begin{array}{l}1.29 \pm 0.08 \\
P 2=0.340 \\
P 3=0.751\end{array}$ \\
\hline Week 5 & $1.27 \pm 0.12$ & $\begin{array}{l}1.32 \pm 0.11 \\
P 1=0.170\end{array}$ & $\begin{array}{l}1.32 \pm 0.07 \\
\mathrm{P} 2=0.169 \\
\mathrm{P} 3=0.735\end{array}$ \\
\hline Week 6 & $1.27 \pm 0.12$ & $\begin{array}{l}1.32 \pm 0.11 \\
\mathrm{P} 1=0.172\end{array}$ & $\begin{array}{l}1.30 \pm 0.06 \\
\mathrm{P} 2=0.306 \\
\mathrm{P} 3=0.442\end{array}$ \\
\hline
\end{tabular}

One way ANOVA test was used with Bonferroni post hoc test. A p-value less than 0.05 was considered statistically significant.

P1 compare group B vs. group A P2 compare group C vs. group A P3 compare group B vs. group C 
Table 3. Comparison between the studied groups regarding the aperture $(\mathrm{cm})$ of Planaxis sulcatus throughout study period, $(\mathrm{n}=24)$

\begin{tabular}{|c|c|c|c|}
\hline \multirow[b]{2}{*}{ Study period } & \multicolumn{3}{|c|}{ Shield aperture $(\mathrm{cm})$} \\
\hline & $\begin{array}{c}\text { Group A } \\
\text { Mean } \pm \text { SD }\end{array}$ & $\begin{array}{c}\text { Group B } \\
\text { Mean } \pm \text { SD }\end{array}$ & $\begin{array}{c}\text { Group C } \\
\text { Mean } \pm \text { SD }\end{array}$ \\
\hline Week 0 & $0.99 \pm 0.14$ & $\begin{array}{l}0.98 \pm 0.08 \\
P 1=0.768\end{array}$ & $\begin{array}{l}0.99 \pm 0.06 \\
P 2=0.937 \\
P 3=0.726\end{array}$ \\
\hline Week 1 & $0.99 \pm 0.14$ & $\begin{array}{l}0.98 \pm 0.08 \\
P 1=0.874\end{array}$ & $\begin{array}{c}0.99 \pm 0.06 \\
P 2=0.874 \\
P 3=1.00\end{array}$ \\
\hline Week 2 & $0.99 \pm 0.13$ & $\begin{array}{l}1.00 \pm 0.08 \\
P 1=0.834\end{array}$ & $\begin{array}{l}1.00 \pm 0.05 \\
\mathrm{P} 2=0.873 \\
\mathrm{P} 3=0.905\end{array}$ \\
\hline Week 3 & $1.00 \pm 0.10$ & $\begin{array}{l}0.99 \pm 0.07 \\
P 1=0.923\end{array}$ & $\begin{array}{c}1.00 \pm 0.05 \\
\mathrm{P} 2=1.00 \\
\mathrm{P} 3=0.882\end{array}$ \\
\hline Week 4 & $0.99 \pm 0.10$ & $\begin{array}{l}1.00 \pm 0.05 \\
P 1=0.913\end{array}$ & $\begin{array}{c}0.99 \pm 0.04 \\
P 2=0.988 \\
P 3=0.869\end{array}$ \\
\hline Week 5 & $0.99 \pm 0.11$ & $\begin{array}{l}1.00 \pm 0.07 \\
\mathrm{P} 1=0.850\end{array}$ & $\begin{array}{l}0.99 \pm 0.05 \\
P 2=0.936 \\
P 3=0.674\end{array}$ \\
\hline Week 6 & $1.00 \pm 0.11$ & $\begin{array}{c}1.00 \pm 0.06 \\
\mathrm{P} 1=1.00\end{array}$ & $\begin{array}{l}0.98 \pm 0.04 \\
P 2=0.687 \\
P 3=0.527\end{array}$ \\
\hline
\end{tabular}

One way ANOVA test was used with Bonferroni post hoc test. A p-value less than 0.05 was considered statistically significant.

P1 compare group B vs. group A

$\mathrm{P} 2$ compare group $\mathrm{C}$ vs. group A

P3 compare group B vs. group C 


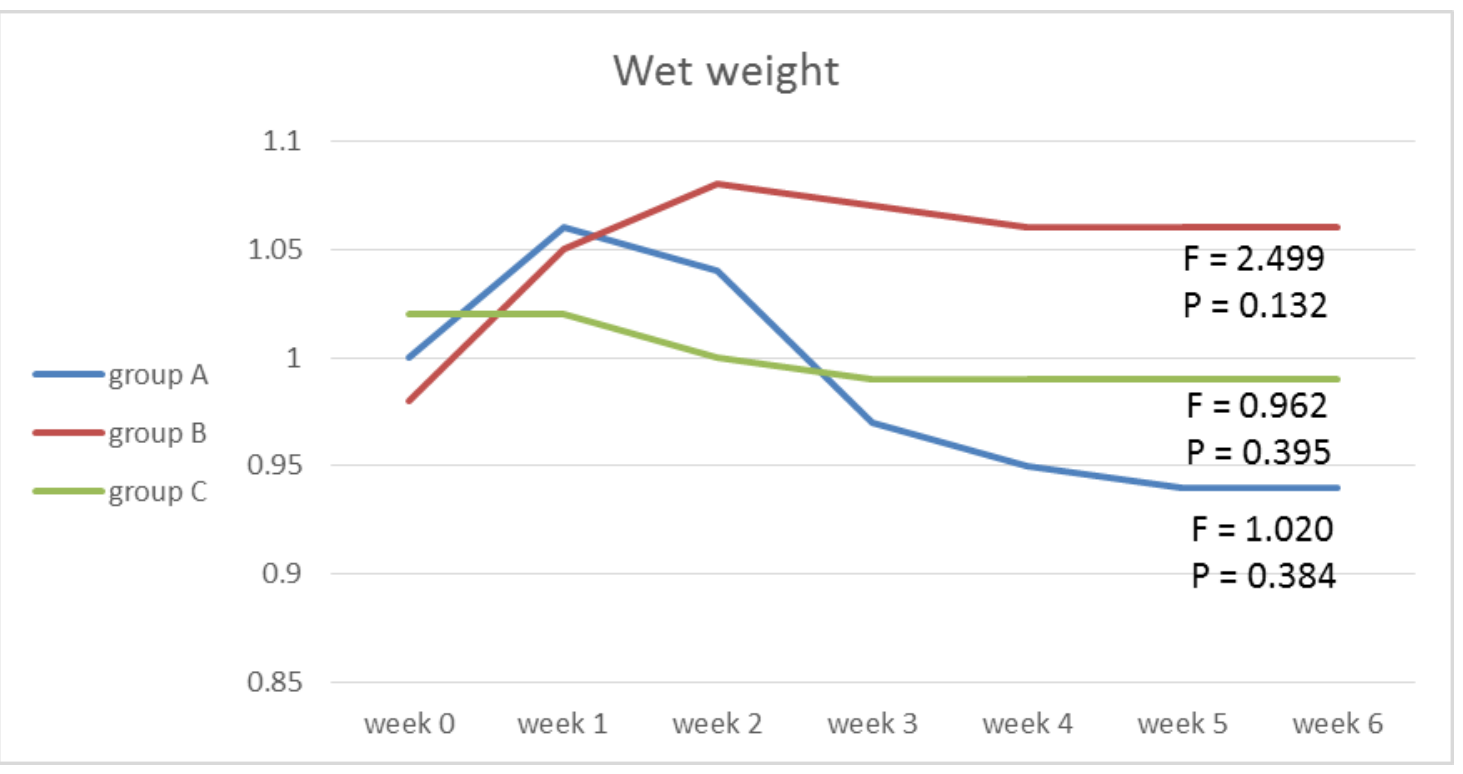

Fig. 1. Mean wet weight (g) of Planaxis sulcatus in the studied groups $\mathrm{C}$ throughout the study period $(n=24)$ using repeated measures. ANOVA test was used with Bonferroni post hoc test. A p-value less than 0.05 was considered statistically significant.

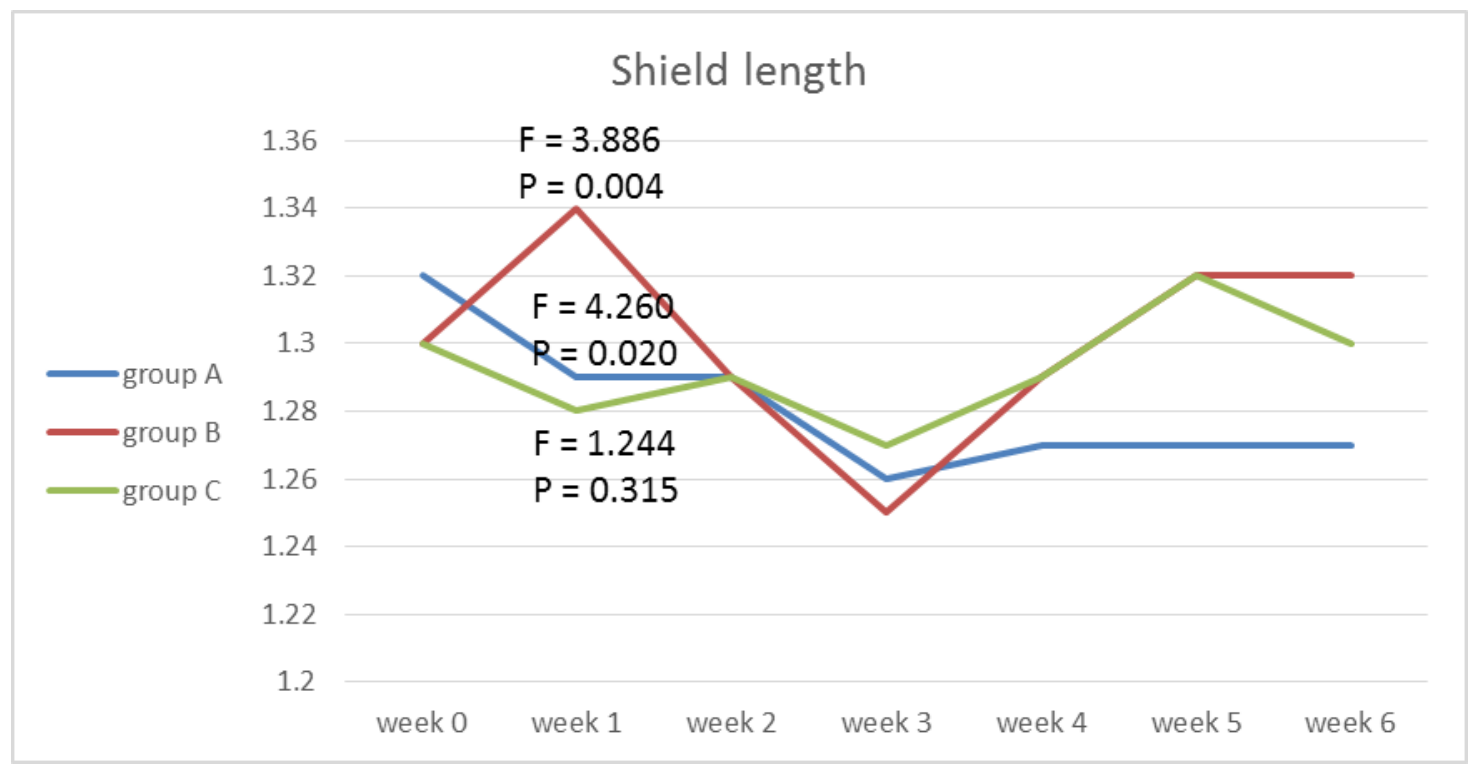

Fig. 2. Mean shield length $(\mathrm{cm})$ of Planaxis sulcatus in the studied groups $\mathrm{C}$ throughout the study period $(n=24)$ using repeated measures. ANOVA test was used with Bonferroni post hoc test. A p-value less than 0.05 was considered statistically significant. 


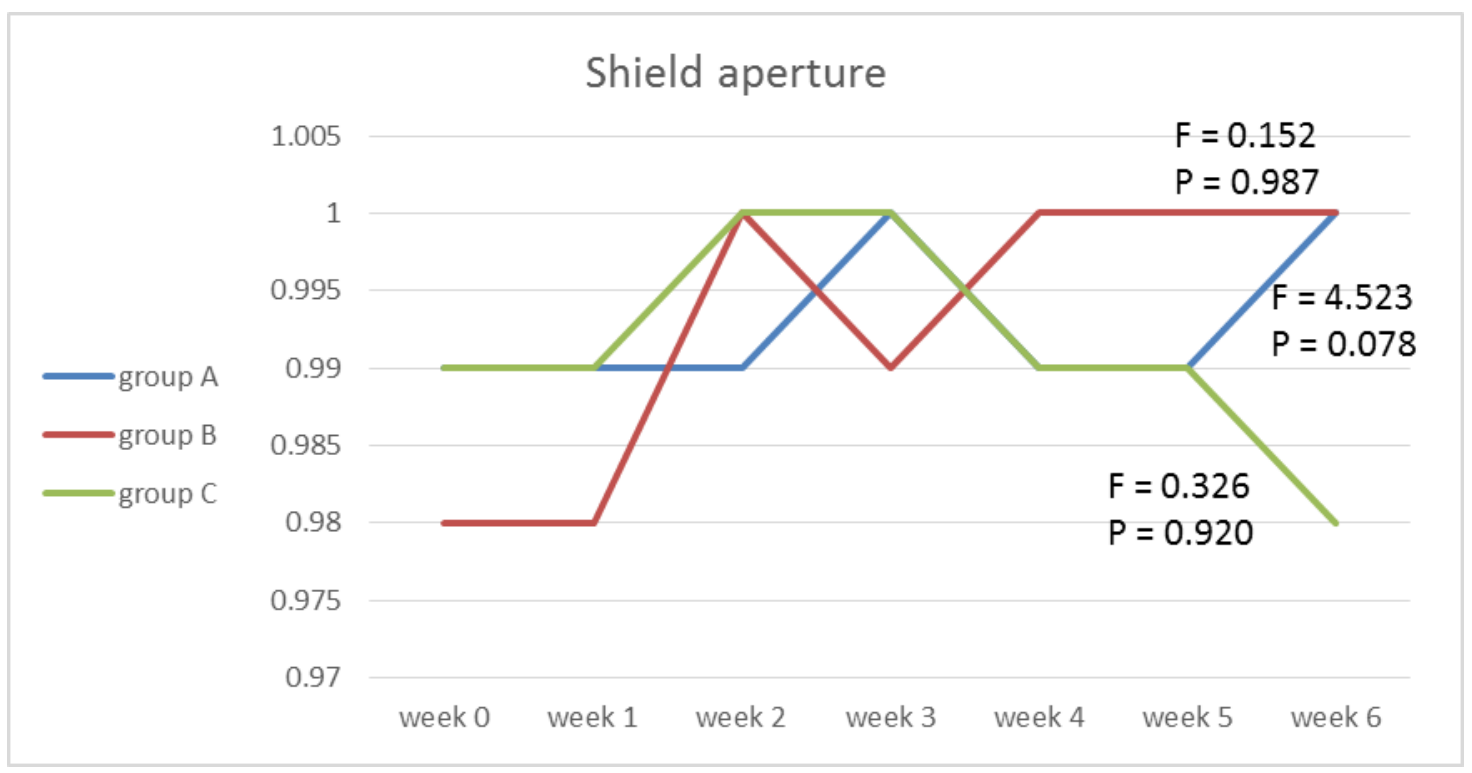

Fig. 3. Mean shield aperture $(\mathrm{cm})$ of Planaxis sulcatus in the studied groups $\mathbf{C}$ throughout the study period $(n=24)$ using repeated measures. ANOVA test was used with Bonferroni post hoc test. A p-value less than 0.05 was considered statistically significant.

\section{DISCUSSION}

There is a high biodiversity in the Red Sea which is located in one of the warmest regions in the world (Dreano et al., 2016). Although species found are small sized, it is still an aquatic ecosystem that has not been studied sufficiently when compared to other water ecosystems such as the Caribbean Sea and the Great Barrier Reef (Bruckner et al., 2013; Berumen et al., 2013). Few studies have examined the impact of temperature elevation on sea snail in the Red Sea, especially at the coast of the kingdom of Saudi Arabia on which almost no studies was conducted.

This study is an experimental animal study including 72 Planaxis sulcatus snails collected form Al-Rais region in the kingdom of Saudi Arabia. This work was organized to study the physiological impact of near future temperature elevation due to climate changes' effect on sea snail growth at the coast of kingdom of Saudi Arabia on the Red Sea. The current findings revealed that, the seawater measurements of temperature, salinity and the $\mathrm{pH}$ increased gradually in group $\mathrm{B}$ and group $\mathrm{C}$. This resulted in no significant differences between weekly measures of the wet weight in intragroup comparison of the three groups A, B and C. In addition, when comparing the 3 groups, wet weight of studied snails also showed no significant differences. However, regarding shield length, it increased at week 1 with pairwise comparison of weekly shield length records that showed only a significant difference between the 1 st week reading and that of the onset of the study in group A; the control group. In group B, the shield length increased at week 6 with pairwise comparison of weekly shield length records showing only a significant difference between week 3 and that of the $6^{\text {th }}$ week. While, group $C$ 
showed no significant differences between weekly measures of shield length. In addition, when comparing the 3 groups, the shield length of the studied snails also showed no significant differences.

The shield aperture of the studied snails showed no significant differences between weekly measures in group A, B and C throughout the study period. Furthermore, when comparing the 3 groups, no significant differences was detected. The present results showing no differences between the control group and others with temperature elevation may be due to acclimation. These results are in accordance with a previous study which investigated acclimation temperature on thermal resistant at upper and lower lethal temperature. Snails acclimated to 10, 20 and 30C showed reasonable heat and cold acclimation (Al-Khateeb, 2006).

This adaptation helps gastropods to survive in environments such as the intertidal zone where low tide temperature exceeds $52^{\circ} \mathrm{C}$ on coasts which are tropical and rocky (Marshall $\boldsymbol{e}$ al., 2013). Organisms living in the low tide zone can tolerate higher temperature (Knox, 2001). The reason for their survival in high temperature may be due to their cone shaped and high-spired shells (Vermeij, 1973).

A previous study concluded that the pyramid-building behavior in the $P$. sulcatus is a thermoregulatory adaptation. Therefore, temperature can be predicted to influence the pyramid-building behavior in the $P$. sulcatus as the previous authors did not observe pyramid-building behavior among the Gulf periwinkles during winter in eastern Bahrain (Kaminski \& Garrison, 2020). But, this behavior was not addressed in the current study.

Eminently, similar changes in depth range can be expected, as species shift down in the water column to escape warm surface waters. While these migrations seem like viable adaptations, it is unclear how successful species can be when moving across these distances and depths. Life history characteristics that rely on other environmental cues, such as day length and tidal cycle, may not adapt fast enough for continued success (Galland et al., 2009).

It is worthy to mention that water warming has many consequences; one of which is elevation of sea level. Water expands and water surface rise when its temperature is elevated. By now, this is limited to the surface layer which is only a few hundred meters deep (Domingues et al., 2008). This heat diffuses overtime to more depth, leading to more expansion and higher sea level due to melting of inland glaciers and continental ice sheets as those resting on Antarctica. Previous studies estimated that sea level would rise by $0.5-0.8 \mathrm{~m}$ over 1990 levels by 2100 , and that this rise might be more than one meter. Recent studies concluded that the mean sea-level rise of 0.5-0.8 m over 1990 levels by 2100 is likely, and that a rise of more than one meter in thae predicted time is possible (Richardson et al., 2009). These significant changes cause more dangerous storm surges and flooding that can occur regularly (McMullen, 2009). Changes in the ocean 
temperature and climate change have significant impact on marine ecosystems and human beings depending on them (Sommerkorn \& Hassol, 2009).

\section{CONCLUSION}

In conclusion, most results were statistically non-significant, which meant no significance difference was detected between the three groups regarding wet weight, shield length and shield aperture. Hence, no relationship was found between temperature elevation and those parameters. Therefore, it is recommended to conduct complex experiments that depend on exposing snails to several climate change factors, such as increased acidity and salinity in addition to high temperature.

\section{ACKNOWLEDGMENTS}

The author would like to thank Hossam Alharbi, Turki ALMuzaini, Eyad Alharbi, Abdulrahman Almughadoi on their effort to collect part of the information in this work.

\section{REFERENCES}

Al-Khateeb, S. O. (2006): "Effect acclimation temperature on thermal resistant in the sea water snail planaxis sulcatus (Born, 1780)," ANBAR JOURNAL OF AGRICULTURAL SCIENCES, 4(1). Available at: https://www.iasj.net/ iasj/article/ 34284 (Accessed: May 1, 2021).

Berumen, M. L.; Hoey, A. S.; Bass, W. H.; Bouwmeester, J.; Catania, D.; Cochran, J. E. M.; ... and Saenz-Agudelo (2013): "The status of coral reef ecology research in the Red Sea," Coral Reefs. Springer, pp. 737-748. doi: 10.1007/s00338-013-1055-8.

Bruckner, A.; Rowlands, G.; Riegl, B.; Purkis, S.; Williams, A. and Renaud, P. (2013): Atlas of Saudi Arabian Red Sea Marine Habitats. Available at: https://www.livingoceansfoundation.org/publication/red-sea-atlas-english/ (Accessed: April 23, 2021).

Bruno, J. F.; Carr, L. A. and O'Connor, M. I. (2015): "Exploring the role of temperature in the ocean through metabolic scaling," Ecology, 96(12): 3126-3140. doi: 10.1890/14-1954.1.

Domingues, C. M.; Church, J. A.; White, N. J.; Gleckler, P. J.; Wijffels, S. E.; Barker, P. M. and Dunn, J. R. (2008): "Improved estimates of upper-ocean warming and multi-decadal sea-level rise," Nature, 453(7198): 1090-1093. doi: 
10.1038/nature07080.

Dore, I. (1991): Shellfish - A Guide to Oysters, Mussels, Scallops, Clams and Similar Products for the Commercial User | Ian Dore | Springer. New York: Van Nostrand Reinhod. Available at: https://www.springer.com/gp/ book/97804 42002039 (Accessed: April 28, 2021).

Dow, K. and Downing, T. E. (2011): The Atlas of Climate Change: Mapping the World's Greatest Challenge by Kirstin Dow. Myriad Editions Limited. Available at: https://www.goodreads.com/book/show/824678.The_Atlas_of_Climate_Ch ange (Accessed: April 23, 2021).

Dreano, D.; Raitsos, D. E.; Gittings, J.; Krokos, G. and Hoteit, I. (2016): "The Gulf of Aden Intermediate Water Intrusion Regulates the Southern Red Sea Summer Phytoplankton Blooms," PLOS ONE. Edited by G. Han, 11(12), p. e0168440. doi: 10.1371/journal.pone.0168440.

Galland, Grantly R. and HerrDorothee (2009): The ocean and climate change: tools and guidelines for action | IUCN. Available at: https://www.iucn.org/content/ ocean-and-climate-change-tools-and-guidelines-action-0 (Accessed: April 23, 2021).

George A. Knox (2001): The Ecology of Seashores - 1st Edition - . USA: Taylor \& Francis Inc. Available at: https://www.routledge.com/The-Ecology-ofSeashores/Knox/ p/book/9780849300080 (Accessed: May 1, 2021).

Gravili, C.; Cozzoli, F. and Boero, F. (2017): "The historical reconstruction of distribution of the genus Halecium (Hydrozoa: Haleciidae): a biological signal of ocean warming?," Marine Biology Research, 13(5): 587-601. doi: 10.1080/17451000.2017.1290805.

Houbrick, R. S. (1987): "Anatomy, reproductive biology, and phylogeny of the Planaxidae (Cerithiacea: Prosobranchia)," Smithsonian Contributions to Zoology, (445): 1-57. doi: 10.5479/si.00810282.445.

Intergovernmental Panel on Climate Change. (2014). Climate Change 2013 - The Physical Science Basis: Working Group I Contribution to the Fifth Assessment Report of the Intergovernmental Panel on Climate Change. Cambridge: Cambridge University Press. doi:10.1017/CBO97811074153 24 
IPCC (2014): Climate Change 2014 Fifth Assessment Synthesis Report - IPCC. Available at: https://ar5-syr.ipcc.ch/ (Accessed: April 23, 2021).

Kaminski, M. A. and Garrison, T. F. (2020): "Thermoregulatory Behavior in the Tropical Periwinkle Planaxis sulcatus," Arabian Journal for Science and Engineering, 45(6): 4817-4822. doi: 10.1007/s13369-019-04300-z.

Kim, D. I.; Matsuyama, Y.; Nagasoe, S.; Yamaguchi, M.; Yoon, Y. H.; Oshima, Y., ... and Honjo, T. (2004): "Effects of temperature, salinity and irradiance on the growth of the harmful red tide dinoflagellate Cochlodinium polykrikoides Margalef (Dinophyceae)," Journal of Plankton Research, 26(1): 61-66. doi: 10.1093/plankt/fbh001.

Levinton JS. (2009): Marine Biology: Function, Biodiversity, Ecology: Levinton, Jeffrey S.: 9780199857128: Amazon.com: Books. Oxford University Press New York.. Available at: https://www.amazon.com/Marine-Biology-FunctionBiodiversity-Ecology/dp/0199857121 (Accessed: April 23, 2021).

Marigómez, I.; Múgica, M.; Izagirre, U. and Sokolova, I. M. (2017): "Chronic environmental stress enhances tolerance to seasonal gradual warming in marine mussels," PLoS ONE, 12(3). doi: 10.1371/journal.pone.0174359.

Marshall, D. J.; Baharuddin, N. and McQuaid, C. D. (2013): "Behaviour moderates climate warming vulnerability in high-rocky-shore snails: Interactions of habitat use, energy consumption and environmental temperature," Marine Biology, 160(9): 2525-2530. doi: 10.1007/s00227-013-2245-1.

Mazurkiewicz, M.; Górska, B.; Renaud, P. E. and Włodarska-Kowalczuk, M. (2020): "Latitudinal consistency of biomass size spectra - benthic resilience despite environmental, taxonomic and functional trait variability," Scientific Reports, 10(1): 1-12. doi: 10.1038/s41598-020-60889-4.

McMullen, C. P. and Jabbour, J. R. (2009): Climate change science compendium 2009| UNEP - UN Environment Programme. United Nations Environment Programme, Nairobi, EarthPrint. Available at: https://www.unep. org/ resources/report/climate-change-science-compendium-2009(Accessed: May 2, 2021).

OHGAKI, S.-I. (1997): "SOME ASPECTS OF THE BREEDING BIOLOGY OF PLANAXIS SULCATUS (BORN) (GASTROPODA: PLANAXIDAE)," 
Journal of Molluscan Studies, 63(1): 49-56. doi: 10.1093/mollus/63.1.49.

Precht and Herbert (1973): "Basic Aspects of Temperature Action on Microorganisms," in Temperature and Life. Springer Berlin Heidelberg: 3-59. doi: 10.1007/978-3-642-65708-5_1.

Richardson, K.; Steffen, W.; Schellnhuber, H. J.; Alcamo, J.; Barker, T.; Kammen, D. M.; ... and Wæver, O. (2009): Climate Change: Global Risk, Challenges and Decisions - Synthesis. Kopenhagen (Vol. 10, p. 12).

Ruppert, E. E. (2004): Invertebrate zoology: a functional evolutionary approach $/ .7$ th ed. Belmont, CA : Thomson-Brooks/Cole,

Sommerkorn, M. and Hassol, S. J. (2009): "Arctic climate feedbacks: global implications," Arctic, 97pp. Available at:http://www.cabdirect.org/ abstracts/20093263949.html.

Vermeij, G. J. (1973): “Adaptation, Versatility, and Evolution,” Systematic Zoology, 22(4): 466. doi: $10.2307 / 2412953$.

Yanzeel, J. H. (1998): “ Studies on some aspects of respiratory physiology and thermal resistance in the fresh water snails Physa acuta (Draparnaud 1805) with special emphasis on the effect of temperature," M. Sc. Thesis, University of Jordan, Jordan. Available at: http://hip.jopuls.org.jo/c/portal/layout? p_l_id=PUB.1.1\&p_p_id=search_WAR_fusion\&p_p_action=1\&p_p_state $=$ normal\&p_p_mode $=$ view $\&$ p_p_col_id $=$ column $-1 \&$ p_p_col_pos $=$ 0\&p_p_col_count=5\&_search_WAR_fusion_action=navigate\&_search_W AR_fusion_navigationData=search \%3D1 \%21BIB \%212147483647 \% 213530944 (Accessed: April 29, 2021). 